\title{
NON-COGNITIVE PREDICTORS OF SUBJECTIVE JOB PERFORMANCE IN A SAMPLE OF MANAGERS, CLIENT SUPPORT AND ADMINISTRATIVE SUPPORT SPECIALISTS
}

\author{
Linda Berga, Ivars Austers \\ University of Latvia, Latvia
}

\begin{abstract}
The present study was designed to distinguish non-cognitive predictors of job performance for various job groups in order to develop a method for identification of the suitability of an employee for positions and career development in organizational settings. This study included personality traits, vocational interests, grit, growth mindset, resistance to change, goal orientation and self-efficacy as potential predictors of job performance from several individual characteristics related to training, learning and job performance found in the literature. The study sample included customer service specialists, support specialists and managers from five different companies in Latvia. The results show that grit, social, conventional, and enterprising interests are significant predictors of subjective job performance. Personality traits, self-efficacy, growth mindset, resistance to change and goal orientation did not predict job performance in this sample. The relationship between subjective job performance and personality traits for conscientiousness and neuroticism is weak. The results are partly in line with other studies. Possible explanations of results and future directions are offered.
\end{abstract}

Keywords: individual characteristics, job performance, personality, vocational interests.

\section{Introduction}

According to individual-environmental fit theories (Edwards, 2008; Kristof-Brown \& Guay, 2011; Su et al., 2015), the congruence between characteristics of employees and characteristics of working environment (e. g. compatibility of personality traits, abilities, and values with job requirements and organizational culture) is essential in the field of career counselling, personnel management and industrial and organizational psychology. Although research on individual differences has been ongoing for 
over 100 years (Sackett et al., 2017), vocational interests are also valid predictor of job performance (Nye et al., 2012, 2017) above and beyond cognitive abilities and personality, in addition to cognitive abilities and personality traits that are stable individual characteristics for predicting job performance (Salgado, Anderson, et al., 2003; Salgado, Moscoso, et al., 2003; Salgado, 2017; Schmidt et al., 2016; Schmidt \& Hunter, 1998). As workplaces change rapidly, the needs of future employees also may change - such skills as flexibility and learning are among the $21^{\text {st }}$ century employability skills (De Fruyt et al., 2015), therefore additional predictors of job performance may be explored. The present study included personality traits, vocational interests, grit, growth mindset, resistance to change, goal orientation and self-efficacy as potential predictors of job performance from a number of individual characteristics discussed in the literature related to training, learning and job performance.

\section{Non-cognitive predictors of training, learning and job performance}

Personality as a stable individual characteristic of employees has been researched in work settings (Rojon et al., 2015; Sackett \& Walmsley, 2014; Salgado, 1997, 2017; Schmidt et al., 2016; Schmidt \& Hunter, 1998). Costa (1996) states that personality can be explained by five core factors - extraversion, agreeableness, openness to experience, conscientiousness, and neuroticism. Two widely studied personality traits in relation to job performance are conscientiousness (Barrick et al., 2001; Costa, 1996; Salgado, 1997) and neuroticism (as opposite to Emotional Stability, John et al., 2008). In recent years (Johnson et al., 2011; Lee et al., 2019), the HEXACO model of personality has been investigated in addition to Five Factor model or Big Five. Those studies conclude that humbleness-humility demonstrates an incremental validity over other individual characteristics in relation to counterproductive job performance (Lee et al., 2019) and is a unique predictor of job performance (Johnson et al., 2011). The impression management strategies used by employees may distort the results of personality profile in high-stakes situations, therefore the forced-choice format of personality assessments has been proposed (Salgado \& Táuriz, 2014; Salgado \& Lado, 2018). Although the faking may not always be prevented (Huber et al., 2021), forced-choice questionnaires are better predictors of job performance if compared to normative or ipsative measures (Salgado \& Táuriz, 2014), therefore this study assesses personality in multidimensional forced-choice format as well.

Based on previous findings, it was expected that:

H1: Conscientiousness would positively correlate to overall job performance. 
H2: Neuroticism would negatively correlate to overall job performance.

H3: Extraversion would positively correlate to overall job performance.

Vocational interests. Vocational interests are trait-like characteristics of motivational and behavioral preferences towards specific environments and activities (Rounds \& Su, 2014). Research on the stability of vocational interests suggests that vocational interests show some stability and changes over time (Hoff et al., 2020; Morris, 2016; Nye et al., 2020; Schultz et al., 2017), similarly to personality traits that show some malleability during lifetime. Holland (1959, 1996) described six types of vocational personalities (RIASEC model) representing realistic, investigative, artistic, social, enterprising and conventional personalities and environments. Although previously referred to as personality types, more recently the RIASEC model has been used as a conceptual framework for interests, not personality (Stoll et al., 2021; $\mathrm{Su}, 2020)$. Recent research has demonstrated that vocational interests are important in work performance (Nye et al., 2012) since interests may influence motivation and goal-attainment through direction, vigor and persistence (Su, 2020). Meta-analytical results of 60 studies conducted until 2010 (Nye et al., 2012) report moderate relationships between job performance and interests in the employee samples. Interest congruence (matching the interest profile with the occupation profile) has higher correlation with job performance than simple interest scores. Meta-analytical results of 92 studies until 2016 (Nye et al., 2017) report baseline correlation with job performance of .16 and interest congruence .32 with job performance. Weaker relationship between interest scores and interest congruence relationship with job performance are reported in meta-analysis of Van Iddekinge (Van Iddekinge, Roth, et al., 2011). This evidence suggests that vocational interests may have the incremental validity for predicting job performance over personality and cognitive abilities (Su, 2020; Van Iddekinge, Putka, et al., 2011). Researchers have noted that personality traits and vocational interests correlate (Barrick et al., 2003; Mount et al., 2005). Additionally, the HEXACO model of personality explains more variance related to vocational interests than the Five Factor model of personality (McKay \& Tokar, 2012). Based on previous findings we formulated a research question for this study:

Q1. Are vocational interests a predictor of overall job performance? To what extent vocational interests add predictive power to personality traits in predicting job performance?

Grit is defined as passion and perseverance toward accomplishing long term goals (Duckworth et al., 2007) and has been studied in educational settings as one of the non-cognitive traits that helps explain success in education above cognitive abilities and conscientiousness. Although some mixed 
results have been received in research on educational success (Ivcevic \& Brackett, 2014) and the validity of the construct of grit have been questioned over conscientiousness (Crede et al., 2016; Ion et al., 2017), the results of the study in a military sector for a high-stress course achievement suggest some usefulness of grittier individuals for predicting success in high-stakes training settings (Farina et al., 2019). Recent review of grit literature (Southwick et al., 2019) suggest that grit may have predictive power in work and organizational settings. In line with previous research, the second research question was proposed as follows:

Q2. Does grit predict job performance above conscientiousness? To what extent grit adds predictive power to personality traits in predicting job performance?

Growth versus fixed mindset. Implicit theories of malleability of individual attributes such as personality, or intelligence have been researched in educational settings in the context of challenge seeking and performance (Dweck \& Yeager, 2019). A fixed mindset (belief that human attributes cannot be changed) is negatively related to academic achievement through personal attributions, performance-avoidance goals and effort beliefs. Although most exclusively researched in educational settings, there is some evidence that implicit beliefs of employees impact their behavior in work settings. In a sample of sales employees (Zingoni \& Corey, 2017) those with more incremental beliefs (growth mindset) had higher job performance $(r=.40)$ and implicit beliefs on personal attributes predicted job performance $(\beta=.45, p<.001)$. In a sample of managers (Heslin \& VandeWalle, 2008), assumptions of personnel impacted their performance evaluation. Regarding relationship with personality traits, growth theory of work is positively related to extroversion, agreeableness, conscientiousness and openness, while destiny (fixed) theory of work is negatively related to agreeableness, conscientiousness, emotional stability and openness (Burnette \& Pollack, 2013). There has also been some criticism of mindset theory (Burgoyne et al., 2020) regarding weak associations with claimed motivational premises. Due to insufficient evidence for growth mindset and relations to job performance, the third research question was proposed:

Q3. Does growth mindset predict overall job performance?

Resistance to change as a dispositional attribute may have implications for work productivity (Bruckman, 2008) along with other organizational outcomes such as turnover, decreased loyalty or higher absenteeism. Across various cultures, resistance to change consists of four factors - emotional reaction, short-term focus, cognitive rigidity and routine seeking behaviors (Oreg et al., 2008). To our knowledge, no study so far has directly addressed the question of resistance to change and job performance, thus we proposed the fourth research question: 
Q4. Is resistance to change negatively related to overall job performance?

Goal orientation refers to goal preferences by individuals in situations related to achievement, it has been proposed to be a dispositional attribute (Theis \& Bipp, 2020) consisting of three dimensions (Vandewalle, 1997) - a) learning goal orientation is choosing work related activities to learn new skills, b) avoiding goal orientation is choosing to avoid work related activities that includes situations where someone might look incompetent, and c) proving-performance goal orientation is choosing work related activities in which individual can demonstrate his/her competence. Dispositional learning goal orientation was positively related to all of the work performance dimensions - learning, task and contextual performance - in an employee sample (Theis \& Bipp, 2020) and to the task performance in a student sample (Yeo et al., 2009). Together with vocational interests, mastery (learning) goal orientation mediates relationship between investigative and enterprising interests and voluntary continuing professional education in a sample of healthcare professionals (Johnson \& Beehr, 2014). In line with those research findings, we proposed the fifth research question:

Q5. Is goal orientation related to overall job performance?

Self-efficacy has been studied jointly with personality and general mental ability in a meta-analytical review of individual differences in predicting task and job performance (Judge et al., 2007). Self-efficacy moderately correlates with work performance as one of the core self-evaluations, although cognitive abilities and personality predict job performance better than self-efficacy. In a review of work-related performance (Stajkovic \& Luthans, 1998), self-efficacy was moderately (.38) related to work performance, thus we proposed the sixth research question:

Q6. Does self-efficacy predict overall job performance above other personality traits?

Non-ability traits, such as social interests, help seeking, peer learning, agreeableness, extraversion, and job performance have been studied in job settings with student samples (Kanfer et al., 2010), where non-ability complexes predicted job performance better than abilities alone. We proposed the final research question, based on the previous research in individual attributes and their relations to job performance:

Q7. Which of the non-cognitive attributes predict job performance in a sample of managers, client support and administrative support specialists? 


\section{Method}

\section{Participants and procedure}

During 2019 and 2020, employees working in five different organizations in Latvia were asked to participate in the study. The final sample consisted of 332 employees of support specialists $(n=52)$, sales and client support specialists $(n=163)$, and supervisors and managers $(n=117)$. $88 \%$ of participants were women, $75 \%$ had a university degree or degrees; age ranged from 18 to 68 years old $(M=39.98, S D=10.83)$ and the average years of tenure was 7.13 ( $M e=4.00$ years). Employees were invited to participate in internet-based survey through the Human Resource departments of the organizations. The personality and interest profiles of employees were provided individually if requested, to motivate completing the survey.

\section{Measures}

Personality traits. Based on Latvian Personality Inventory (LPA v-3; Perepjolkina \& Renge, 2013) a multi-dimensional forced-choice personality inventory was designed for this study. The questionnaire consisted of 18 blocks of 4-choice-statements representing different personality factors (humility, extraversion, conscientiousness, agreeableness, openness and neuroticism). In each of the blocks respondents marked one statement that describes him/her the most and one statement that describes him/ her the least. A sample item is provided in Table 1, a respondent chooses one of the four items in a block that describe him/her the most and one of the four items that describes him/her the least. A pilot study of this questionnaire in a sample of students $(n=178)$ revealed acceptable convergent validity ( .62 to .73 for conscientiousness, openness, extraversion, and neuroticism) in traits respective to Big Five questionnaire, except for agreeableness ( .48).

Table 1. A sample of personality forced-choice item block 1 with respective personality factors

\begin{tabular}{|l|l|}
\hline Block 1 & Respective personality factor \\
\hline I am very accurate person & Conscientiousness \\
\hline I cannot lie & Humbleness - Humility \\
\hline $\begin{array}{l}\text { I do not take the initiative to meet other } \\
\text { people }\end{array}$ & Extraversion \\
\hline $\begin{array}{l}\text { I sometimes tend to be sarcastic and } \\
\text { vitriolic }\end{array}$ & Agreeableness \\
\hline
\end{tabular}


Vocational interests. Latvian Questionnaire of Vocational Interests (LQVI; Berga \& Austers, 2021) based on Holland's (1996) RIASEC model measured six scales of vocational interests (realistic (R), investigative (I), artistic (A), social (S), enterprising (E) and conventional (C)). Two control questions were included to eliminate those who responded carelessly (e. g., please, select the option 'disagree'). Internal reliability of LQVI interest scales are as follows (Berga \& Austers, 2021): realistic $\alpha=.77$, investigative $\alpha=.81$, artistic $\alpha=.83$, social $\alpha=.79$, enterprising $\alpha=.84$, and conventional $\alpha=.77$ (for full LQVI development and items refer to Berga \& Austers, 2021).

Grit was measured with the Short Grit scale (Grit-S; Duckworth \& Quinn, 2009) that was adapted in Latvian for this study. The scale consisted of eight questions measuring the perseverance of effort and the consistency of interests.

Growth mindset. 'Kind of Person' Implicit Theory Scale (Dweck, 1999; Dweck et al., 1995) that was adapted in Latvian for this study was used to measure growth mindset. The scale consisted of eight statements measuring growth or fixed mindset.

Resistance to change. Resistance to change scale (Oreg, 2003) consisting of 17 statements was used to measure four subscales of dispositional resistance to change: routine seeking, emotional reaction, short-term thinking and cognitive rigidity. The scale was adapted in Latvian for this study.

Goal orientation. Goal orientation questionnaire (GO; VandeWalle, 1997) consisting of 12 statements measured three goal orientations: learning goal orientation, proving-performance goal orientation and avoiding-performance goal orientation.

Self-efficacy. General self-efficacy scale (GSE; Schwarzer \& Jerusalem, 1995) consisting of 10 statements was modified and adapted in Latvian for this study. To ensure the similarity of various Likert scales, the answers were provided in 5-point Likert scale instead of 4-point Likert scale as in original.

Job performance was measured by 3 statements of subjective job performance questions ("Overall, how do you rate your job performance during the last 6 months?" and "How do you think your supervisor... " and "How do you think your peers..." depending on the perspective a respondent had to take). The question was answered on a scale from 1 - unsatisfactory to 10 - excellent. Averaged result of subjective, subjective-supervisor and subjective-peer rating was calculated as overall subjective job performance measure. 


\section{Results}

Table 2 summarizes the descriptive statistics of individual variables measured and correlations with subjective job performance.

Table 2. Descriptive statistics and Spearman's rank-order correlation for study variables $(n=332)$

\begin{tabular}{|c|c|c|c|c|}
\hline Variable & Dimensions & $M$ & $S D$ & Job Performance \\
\hline Job performance & & 7.83 & 1.04 & - \\
\hline \multirow[t]{6}{*}{ Vocational Interests } & Realistic & 32.26 & 6.82 & .00 \\
\hline & Investigative & 29.22 & 6.16 & -.01 \\
\hline & Artistic & 27.68 & 7.52 & -.00 \\
\hline & Social & 34.66 & 5.79 & .01 \\
\hline & Enterprising & 33.65 & 7.21 & $.17^{* *}$ \\
\hline & Conventional & 38.35 & 5.45 & $.14^{* *}$ \\
\hline \multirow[t]{6}{*}{ Personality traits } & Conscientiousness & 14.47 & 4.12 & $.17^{* *}$ \\
\hline & Humility & 15.28 & 2.92 & .00 \\
\hline & Extraversion & 14.26 & 3.96 & .06 \\
\hline & Agreeableness & 13.51 & 3.34 & .02 \\
\hline & Openness & 13.05 & 2.92 & -.11 \\
\hline & Neuroticism & 11.76 & 3.85 & $-.12^{*}$ \\
\hline Grit & & 3.55 & .47 & $.30^{* * *}$ \\
\hline Self-efficacy & & 3.60 & .57 & $.14^{*}$ \\
\hline \multirow[t]{3}{*}{ Goal orientation (GO) } & Learning GO & 3.78 & .71 & .06 \\
\hline & Performance GO & 3.40 & .88 & .03 \\
\hline & Avoiding GO & 2.73 & .87 & -.08 \\
\hline \multirow[t]{4}{*}{ Resistance to change } & Routing seeking & 2.51 & .78 & -.03 \\
\hline & Emotional reaction & 3.32 & .86 & -.03 \\
\hline & Cognitive rigidity & 3.48 & .72 & .08 \\
\hline & Short-term focus & 2.69 & .77 & .00 \\
\hline Growth mindset & & 3.36 & .79 & .07 \\
\hline \multirow[t]{4}{*}{ Demographic variables } & Tenure in organization & 11.21 & 9.52 & .05 \\
\hline & Tenure in occupation & 7.48 & 8.59 & .02 \\
\hline & Age & 40.33 & 10.87 & .03 \\
\hline & Gender & $1.10^{\mathrm{a}}$ & .31 & -.10 \\
\hline
\end{tabular}

Note. ${ }^{\text {a }}$ - male coded as 1 , female as 2

$* p<.05 ; * * p<.01$ 
The first hypothesis was confirmed: conscientiousness was positively, but weakly, related to job performance $\left(r_{s}=.17, p<.01\right)$. The second hypothesis was also confirmed: neuroticism (as opposite to emotional stability) was negatively, but weakly, related to overall job performance $\left(r_{s}=-.12, p<.05\right)$. The third hypothesis was rejected: extraversion was not related to job performance.

With respect to research questions number 3,4 and 5 there were no statistically significant correlations, neither growth mindset, neither goal orientations, nor resistance to change were related to job performance in a sample of managers, client support and administrative support specialists.

To answer the research questions number 1, 2, 6 and 7 - whether vocational interests, grit, self-efficacy, and other non-cognitive variables predict job performance, stepwise regression analysis with all these variables as predictors was performed on job performance as a criterion variable. Due to some missing data that respondents did not want to disclose, the final sample consisted of 301 participants for regression analysis. Results of regression analysis suggest that grit is predictive of job performance $(\beta=.25, p<.01)$, and adding vocational interests - conventional, enterprising, and social - in a model explains $13 \%$ of variance in subjective job performance (Model 4 in Table 3). Regarding the first research question with respect to vocational interests as predictors of job performance in a sample of managers, client support and administrative support specialists, conventional interests (in Model $5, \beta=.20, p<.01$ ), enterprising interests (in Model $5, \beta=.25, p<.01$ ) and social interests, albeit negatively (in Model $5, \beta=-.17, p<.05$ ), were statistically significant predictors of job performance, together with grit and gender they explained $14 \%$ of variation in job performance. Regarding the second research question about grit as a predictor of job performance - grit alone can explain $6 \%$ of variation in job performance (Model $1, \beta=.25, p<.01, R^{2}=.06$ ). Regarding research question number six - self-efficacy was not a statistically significant predictor of job performance as it was excluded from the regression model.

And overall, regarding final research question - which of the non-cognitive attributes predict job performance in a sample of managers, client support and administrative support specialists - five statistically significant predictors were found in regression analysis (Model 5) - grit, conventional interests, enterprising interests, social interests, and gender $(r=.38$, $p<.01 ; R^{2}=.14$ ) explaining $14 \%$ of variance in subjective job performance measure. 
Table 3. Stepwise linear regression model for predicting subjective job performance $(n=301)$

\begin{tabular}{|c|c|c|c|c|c|}
\hline & Predictor & $b$ & beta & Fit & Difference \\
\hline \multirow[t]{3}{*}{ Model 1} & (constant) & $5.89 * *$ & & & \\
\hline & Grit & $.55^{* *}$ & $.25^{* *}$ & & \\
\hline & & & & $\mathrm{R}^{2}=.06 * *$ & \\
\hline \multirow[t]{4}{*}{ Model 2} & (constant) & $4.91 * *$ & & & \\
\hline & Grit & $.46 * *$ & $.21 * *$ & & \\
\hline & $\begin{array}{l}\text { Conventional } \\
\text { interests }\end{array}$ & $.03 * *$ & $.18 * *$ & & \\
\hline & & & & $\mathrm{R}^{2}=.09 * *$ & $\Delta \mathrm{R}^{2}=.03^{* * *}$ \\
\hline \multirow[t]{5}{*}{ Model 3} & (constant) & $4.24 * *$ & & & \\
\hline & Grit & $.41 * *$ & $.18 * *$ & & \\
\hline & $\begin{array}{l}\text { Conventional } \\
\text { interests }\end{array}$ & $.04 * *$ & $.19 * *$ & & \\
\hline & $\begin{array}{l}\text { Enterprising } \\
\text { interests }\end{array}$ & $.02 * *$ & $.15^{* *}$ & & \\
\hline & & & & $\mathrm{R}^{2}=.11 * *$ & $\Delta \mathrm{R}^{2}=.02 * *$ \\
\hline \multirow[t]{6}{*}{ Model 4} & (constant) & $4.64^{* * *}$ & & & \\
\hline & Grit & $.39 * *$ & $.17 * *$ & & \\
\hline & $\begin{array}{l}\text { Conventional } \\
\text { interests }\end{array}$ & $.04 * *$ & $.22 * *$ & & \\
\hline & $\begin{array}{l}\text { Enterprising } \\
\text { interests }\end{array}$ & $.03 * *$ & $.23 * *$ & & \\
\hline & Social interests & $-.03 *$ & $-.15^{*}$ & & \\
\hline & & & & $\mathrm{R}^{2}=.13^{* * *}$ & $\Delta \mathrm{R}^{2}=.02^{*}$ \\
\hline \multirow[t]{7}{*}{ Model 5} & (constant) & $5.50 * *$ & & & \\
\hline & Grit & $.35 * *$ & $.16 * *$ & & \\
\hline & $\begin{array}{l}\text { Conventional } \\
\text { interests }\end{array}$ & $.04 * *$ & $.20 * *$ & & \\
\hline & $\begin{array}{l}\text { Enterprising } \\
\text { interests }\end{array}$ & $.04 * *$ & $.25^{* *}$ & & \\
\hline & Social interests & $-.03 *$ & $-.17 *$ & & \\
\hline & Gender & $-.44 *$ & $-.13 *$ & & \\
\hline & & & & $\mathrm{R}^{2}=.14^{* * *}$ & $\Delta \mathrm{R}^{2}=.02^{*}$ \\
\hline
\end{tabular}

Note. $* p<.05 ; * * p<.01 . b$-unstandardized regression weights, beta-standardized regression weights 


\section{Discussion}

The purpose of this study was to test which non-cognitive individual attributes are predictive of subjective job performance in a sample of managers, client support and administrative support specialists working in various organizations. Although general mental abilities have been widely accepted as most predictive of work-related performance (Bertua et al., 2005; Gonzalez-Mulé et al., 2014; Salgado, Moscoso, et al., 2003; Schmidt \& Hunter, 1998) such individual characteristics as personality traits, vocational interests and other self-concepts has been researched in work settings as well (Judge et al., 2007; Nye et al., 2012; Sackett et al., 2017).

Two of three study hypotheses were confirmed - conscientiousness and neuroticism from personality traits are related to job performance in line with the previous research. Although it is worth noting the correlations were weak in comparison to the meta-analytical studies where averaged correlation was .27 (Barrick et al., 2001). The relations of these traits may be lower as the multidimensional format of forced choices may not capture the variability of personality traits as good as Likert-type measures due to the specific measurement of personality traits. Third hypothesis - that extraversion will be positively related to job performance - was rejected. The results are somewhat surprising due to the advantages of extraversion in the contemporary world of work (Wilmot et al., 2019) and the sample of employees that include close relations with others (managing and consulting, supporting others). One possible explanation for this is the forcedchoice multidimensional measure of personality that sometimes forces one to mark statements as the most important characteristic even if the statement is not fully characteristic of an individual, which contrasts with Likert-type scales that are used in the majority of cases. Other explanation of this finding may be due to various professions included in the sample managers should be more assertive due to task demands in working with others, and some administrative support specialists, for example, an office administrator in relation to job performance should be more oriented to details as compared to being social and assertive. Third, the gathering of data was conducted during the time of restricted social contacts due to COVID-19 pandemic, so the advantages of extraversion may not fully manifest itself in telework settings.

The present study sheds light on how vocational interests can be used in predicting job performance. This study demonstrates that vocational interests should be included as one of the variables in the research of job performance although previously it has been neglected variable in personnel selection and training (e. g., Schmidt \& Hunter, 1998; Nye et al., 2012). Conventional, enterprising, and social interests were predictive of 
job performance in this sample - vocational interests as an individual characteristic help to explain why some of the employees are more successful in their jobs than others. In line with recent meta-analytical conclusions (Nye et al., 2012, 2017), vocational interests should be added to individual characteristics that may distinguish higher achievers. Although unexpectedly, social interests predicted subjective job performance negatively in this sample, and this is somewhat surprising, given that Holland's theory of vocational personalities state that those with more expressed social interests should be more productive in an environment that is related to helping or training others. One possible explanation for this may be that those who are more prone to helping behaviors may sometimes be counterproductive by choosing to spend more time helping others rather than engaging in their individual work tasks.

Regarding research questions of other individual characteristics - grit, growth mindset, resistance to change, goal orientation and self-efficacy - as potential predictors of job performance, only grit positively predicted subjective job performance. As some researchers note (Crede et al., 2016), grit may not be distinctive from the personality conscientiousness trait. If this is the case, the dominance of grit in the prediction of job performance may not be that surprising - perseverance for long-term goals and accomplishing those goals may be the most relevant characteristic of job performance in a contemporary job environment.

This study has some practical implications in relation to vocational interest measures in work settings. As a previously neglected characteristic of individual attributes that shape educational choice ( $\mathrm{Su}, 2020$ ), the research of vocational interests should be more explored in work settings. If vocational interests are valid predictors of job performance in the sample of a present study, that implies the use of vocational interests in other applied settings such as personnel placement or even in job transitions. Future research should explore the congruence between vocational interests and the work environment as the congruence of interests are stronger related to job performance (Nye et al., 2017) to better understand the interest-performance relations in work settings.

Some limitations of study must be mentioned as well. Firstly, regarding the sample of employees - the participation was voluntary, the sample consisted mostly of women, therefore the sample was not representative of the employee population. Secondly, all the measures of performance were self-reported, that is subjective, and may not reflect the performance as observed by supervisors or may not be objective measures of work performance. Thirdly, only an overall job performance measure was included in the study, although work performance may be studied as a multidimensional construct that includes task performance, contextual performance, 
and counterproductive performance. Future studies should explore whether different work-related constructs are differently related to various dimensions of work performance.

\section{Conclusions}

- This study confirms that some personality traits and vocational interests are related to job performance, specifically, conscientiousness, neuroticism from personality traits and conventional and enterprising interests from vocational interests.

- Grit as perseverance to long-term goals was the most valid predictor of job performance in a sample of managers, client support and administrative support specialists.

- Future research should explore interest-performance, personality-performance, and grit-performance relations in more detail under conditions of various forms of work performance.

\section{Acknowledgement}

The study reported in this paper was a part of the research project "Development of an Assessment Method for Employee Careers" by TET, University of Latvia and Latvian Personnel Management Association.

\section{References}

Barrick, M. R., Mount, M. K., \& Gupta, R. (2003). Meta-analysis of the relationship between the five-factor model of personality and Holland's occupational types. Personnel Psychology, 56(1), 45-74. https://doi.org/10.1111/j.1744-6570.2003.tb00143.x

Barrick, M. R., Mount, M. K., \& Judge, T. A. (2001). Personality and performance at the beginning of the new millennium: What do we know and where do we go next? International Journal of Selection and Assessment, 9(1-2), 9-30. https://doi. org/10.1111/1468-2389.00160

Berga, L., \& Austers, I. (2021). Using vocational interests in job settings: Development and validation of a questionnaire for vocational interests in Latvian. The International Journal of Interdisciplinary Social and Community Studies, 16(2), 1-12. https://doi.org/ https://doi.org/10.18848/2324-7576/CGP/v16i02/1-12

Bertua, C., Anderson, N., \& Salgado, J. F. (2005). The predictive validity of cognitive ability tests: A UK meta-analysis. Journal of Occupational and Organizational Psychology, 78(3), 387-409. https://doi.org/10.1348/096317905X26994

Bruckman, J. C. (2008). Overcoming resistance to change: Causal factors, interventions, and critical values. The Psychologist-Manager Journal, 11(2), 211-219. https://doi. org $/ 10.1080 / 10887150802371708$

Burgoyne, A. P., Hambrick, D. Z., \& Macnamara, B. N. (2020). How firm are the foundations of Mind-Set Theory? The claims appear stronger than the evidence. Psychological Science, 31(3), 258-267. https://doi.org/10.1177/0956797619897588 
Burnette, J. L., \& Pollack, J. M. (2013). Implicit Theories of work and job fit: Implications for job and life satisfaction. Basic and Applied Social Psychology, 35(4), 360-372. https:// doi.org/10.1080/01973533.2013.803964

Costa, P. T. (1996). Work and personality: Use of the NEO-PI-R in industrial/ organisational psychology. Applied Psychology, 45(3), 225-241. https://doi.org/10.1111/ j.1464-0597.1996.tb00766.x

Crede, M., Tynan, M. C., \& Harms, P. D. (2016). Much ado about grit: A meta-analytic synthesis of the grit literature. Journal of Personality and Social Psychology, 113(3), 492511.

De Fruyt, F., Wille, B., \& John, O. P. (2015). Employability in the $21^{\text {st }}$ century: Complex (interactive) problem solving and other essential skills. Industrial and Organizational Psychology, 8(2), 271-281. https://doi.org/10.1017/iop.2015.33

Duckworth, A. L., Peterson, C., Matthews, M. D., \& Kelly, D. R. (2007). Grit: Perseverance and passion for long-term goals. Journal of Personality and Social Psychology, 92(6), 1087-1101. https://doi.org/10.1037/0022-3514.92.6.1087

Duckworth, A. L., \& Quinn, P. D. (2009). Development and validation of the short Grit Scale (Grit-S). Journal of Personality Assessment, 91(2), 166-174. https://doi. org/10.1080/00223890802634290

Dweck, C. S. (1999). Self-theories: Their Role in motivation, personality, and development (1 ${ }^{\text {st }}$ ed.). Psychology Press. https://doi.org/10.4324/9781315783048

Dweck, C. S., Chiu, C., \& Hong, Y. (1995). Implicit Theories and their role in judgments and reactions : A world from two perspectives. Psychological Inquiry, 6(4), 267-285.

Dweck, C. S., \& Yeager, D. S. (2019). Mindsets: A view from two eras. Perspectives on Psychological Science, 14(3), 481-496. https://doi.org/10.1177/1745691618804166

Edwards, J. R. (2008). Person-Environment fit in organizations: An assessment of theoretical progress. The Academy of Management Annals, 2(1), 167-230. https://doi. org/10.1080/19416520802211503

Farina, E. K., Thompson, L. A., Knapik, J. J., Pasiakos, S. M., McClung, J. P., \& Lieberman, H. R. (2019). Physical performance, demographic, psychological, and physiological predictors of success in the U.S. Army Special Forces Assessment and Selection course. Physiology and Behavior, 210(March), 112647. https://doi.org/10.1016/j.physbeh.2019.112647

Gonzalez-Mulé, E., Mount, M. K., \& Oh, I. S. (2014). A meta-analysis of the relationship between general mental ability and nontask performance. Journal of Applied Psychology, 99(6), 1222-1243. https://doi.org/10.1037/a0037547

Heslin, P. A., \& VandeWalle, D. (2008). Managers' implicit assumptions about personnel. Current Directions in Psychological Science, 17(3), 219-223. https://doi.org/10.1111/ j.1467-8721.2008.00578.x

Hoff, K. A., Song, Q. C., Einarsdóttir, S., Briley, D. A., \& Rounds, J. (2020). Developmental structure of personality and interests: A four-wave, 8-year longitudinal study. Journal of Personality and Social Psychology, 118(5), 1044-1064. https://doi.org/10.1037/ pspp0000228

Holland, J. L. (1959). A theory of vocational choice. Journal of Counseling Psychology, 6(1), 35-45. https://doi.org/10.1037/h0040767

Holland, J. L. (1996). Exploring careers with typology. American Psychologist, 51(4), 397-406. 
Huber, C. R., Kuncel, N. R., Huber, K. B., Boyce, A. S., Huber, C. R., Kuncel, N. R., \& Huber, K. B. (2021). Faking and the validity of personality tests: An experimental investigation using modern forced choice measures. Personnel Assessment and Decisions, $7(1), 20-30$.

Ion, A., Mindu, A., \& Gorbănescu, A. (2017). Grit in the workplace: Hype or ripe? Personality and Individual Differences, 111, 163-168. https://doi.org/10.1016/j.paid. 2017.02.012

Ivcevic, Z., \& Brackett, M. (2014). Predicting school success: Comparing Conscientiousness, Grit, and Emotion Regulation Ability. Journal of Research in Personality, 52, 29-36. https://doi.org/10.1016/j.jrp.2014.06.005

John, O. P., Naumann, L. P., \& Soto, C. J. (2008). Paradigm shift to the integrative Big Five trait taxonomy: History, measurement, and conceptual issues. In Handbook of personality: Theory and research (pp. 114-158). The Guilford Press.

Johnson, M. K., Rowatt, W. C., \& Petrini, L. (2011). A new trait on the market: HonestyHumility as a unique predictor of job performance ratings. Personality and Individual Differences, 50(6), 857-862. https://doi.org/10.1016/j.paid.2011.01.011

Johnson, V. A., \& Beehr, T. A. (2014). Making use of professional development: Employee interests and motivational goal orientations. Journal of Vocational Behavior, 84(2), 99-108. https://doi.org/10.1016/j.jvb.2013.12.003

Judge, T. A., Jackson, C. L., Shaw, J. C., Scott, B. A., \& Rich, B. L. (2007). Self-efficacy and work-related performance: The integral role of individual differences. Journal of Applied Psychology, 92(1), 107-127. https://doi.org/10.1037/0021-9010.92.1.107

Kanfer, R., Wolf, M. B., Kantrowitz, T. M., \& Ackerman, P. L. (2010). Ability and trait complex predictors of academic and job performance: A person-situation approach. Applied Psychology, 59(1), 40-69. https://doi.org/10.1111/j.1464-0597.2009.00415.x

Kristof-Brown, A., \& Guay, R. P. (2011). Person-environment fit. In APA handbook of industrial and organizational psychology, Vol 3: Maintaining, expanding, and contracting the organization. (pp. 3-50). American Psychological Association. https://doi. org/10.1037/12171-001

Lee, Y., Berry, C. M., \& Gonzalez-Mulé, E. (2019). The importance of being humble: A meta-analysis and incremental validity analysis of the relationship between honestyhumility and job performance. Journal of Applied Psychology, 104(12), 1535-1546. https://doi.org/10.1037/apl0000421

McKay, D. A., \& Tokar, D. M. (2012). The HEXACO and five-factor models of personality in relation to RIASEC vocational interests. Journal of Vocational Behavior, 81(2), 138149. https://doi.org/10.1016/j.jvb.2012.05.006

Morris, M. L. (2016). Vocational interests in the United States: Sex, age, ethnicity, and year effects. Journal of Counseling Psychology, 63(5), 604-615. https://doi.org/10.1037/ cou0000164

Mount, M. K., Barrick, M. R., Scullen, S. M., \& Rounds, J. (2005). Higher-order dimensions of the Big Five personality traits and the Big Six vocational interest types. Personnel Psychology, 58(2), 447-478. https://doi.org/10.1111/j.1744-6570.2005.00468.x

Nye, C. D., Su, R., Rounds, J., \& Drasgow, F. (2012). Vocational interests and performance: A quantitative summary of over 60 years of research. Perspectives on Psychological Science, 7(4), 384-403. https://doi.org/10.1177/1745691612449021

Nye, C. D., Su, R., Rounds, J., \& Drasgow, F. (2017). Interest congruence and performance: Revisiting recent meta-analytic findings. Journal of Vocational Behavior, 98, 138-151. https://doi.org/10.1016/j.jvb.2016.11.002 
Nye, C. D., Wille, B., Amory, J., \& De Fruyt, F. (2020). Are work activities related to interest change over time? A 22-year longitudinal study. Journal of Personality and Social Psychology. https://doi.org/10.1037/pspp0000360

Oreg, S. (2003). Resistance to Change Scale. Journal of Applied Psychology, 88(4), 680693. https://doi.org/10.1037/0021-9010.88.4.680

Oreg, S., Bayazit, M., Vakola, M., Arciniega, L., Armenakis, A., Barkauskiene, R., Bozionelos, N., Fujimoto, Y., González, L., Han, J., Hřebíčková, M., Jimmieson, N., Kordačová, J., Mitsuhashi, H., Mlačić, B., Ferić, I., Topić, M. K., Ohly, S., Saksvik, P. Ø., ... van Dam, K. (2008). Dispositional resistance to change: Measurement equivalence and the link to personal values across 17 nations. Journal of Applied Psychology, 93(4), 935-944. https://doi.org/10.1037/0021-9010.93.4.935

Perepjolkina, V., \& Renge, V. (2013). Latvijas Personïbas aptauja (LPA-v3). Testa rokasgrāmata.

Rojon, C., McDowall, A., \& Saunders, M. N. K. (2015). The relationships between traditional selection assessments and workplace performance criteria specificity: A comparative meta-analysis. Human Performance, 28(1), 1-25. https://doi.org/10.108 0/08959285.2014.974757

Rounds, J., \& Su, R. (2014). The Nature and Power of Interests. Current Directions in Psychological Science, 23(2), 98-103. https://doi.org/10.1177/0963721414522812

Sackett, P. R., Lievens, F., Van Iddekinge, C. H., \& Kuncel, N. R. (2017). Individual differences and their measurement: A review of 100 years of research. Journal of Applied Psychology, 102(3), 254-273. https://doi.org/10.1037/ap10000151

Sackett, P. R., \& Walmsley, P. T. (2014). Which personality attributes are most important in the workplace? Perspectives on Psychological Science, 9(5), 538-551. https://doi. org/10.1177/1745691614543972

Salgado, J. F. (1997). The five factor model of personality and job performance in the European Community. Journal of Applied Psychology, 82(1), 30-42. https://doi. org/10.1037//0021-9010.82.1.30

Salgado, J. F. (2017). Personnel Selection. In Oxford Research Encyclopedia of Psychology (pp. 1-29). Oxford University Press USA. https://doi.org/10.1093/ acrefore/9780190236557.013.8

Salgado, J. F., Anderson, N., Moscoso, S., Bertua, C., \& De Fruyt, F. (2003). International validity generalization of GMA and cognitive abilities: A European Community meta-analysis. Personnel Psychology, 56(3), 573-605. https://doi. org/10.1111/j.1744-6570.2003.tb00751.x

Salgado, J. F., Anderson, N., \& Tauriz, G. (2015). The validity of ipsative and quasiipsative forced-choice personality inventories for different occupational groups: A comprehensive meta-analysis. Journal of Occupational and Organizational Psychology, 88(4), 797-834. https://doi.org/10.1111/joop.12098

Salgado, J. F., \& Lado, M. (2018). Faking resistance of a quasi-ipsative forced-choice personality inventory without algebraic dependence. Journal of Work and Organizational Psychology, 34(3), 213-216. https://doi.org/10.5093/jwop2018a23

Salgado, J. F., Moscoso, S., De Fruyt, F., Anderson, N., Bertua, C., \& Rolland, J. P. (2003). A meta-analytic study of general mental ability validity for different occupations in the European community. Journal of Applied Psychology, 88(6), 1068-1081. https:// doi.org/10.1037/0021-9010.88.6.1068

Salgado, J. F., \& Táuriz, G. (2014). The Five-Factor Model, forced-choice personality inventories and performance: A comprehensive meta-analysis of academic and 
occupational validity studies. European Journal of Work and Organizational Psychology, 23(1), 3-30. https://doi.org/10.1080/1359432X.2012.716198

Schmidt, F. L., \& Hunter, J. E. (1998). The validity and utility of selection methods in personnel psychology: Practical and theoretical implications of 85 years of research findings. Psychological Bulletin, 124(2), 262-274. https://doi.org/10.1037//00332909.124.2.262

Schmidt, F. L., Oh, I.-S., \& Shaffer, J. A. (2016). The validity and utility of selection methods in personnel psychology: Practical and theoretical implications of 100 years of research findings. https://doi.org/10.13140/RG.2.2.18843.26400

Schultz, L. H., Connolly, J. J., Garrison, S. M., Leveille, M. M., \& Jackson, J. J. (2017). Vocational interests across 20 years of adulthood: Stability, change, and the role of work experiences. Journal of Research in Personality, 71, 46-56. https://doi.org/10.1016/j. jrp.2017.08.010

Schwarzer, R., \& Jerusalem, M. (1995). Generalized self-efficacy scale. In J. Weinman, S. Wright, \& M. Johnston (Eds.), Measures in health psychology: A user's portfolio. Causal and control beliefs (pp. 35-37). Windsor, England: NFER-NELSON.

Southwick, D. A., Tsay, C. J., \& Duckworth, A. L. (2019). Grit at work. Research in Organizational Behavior, 39(2019), 100126. https://doi.org/10.1016/j.riob.2020.100126

Stajkovic, A. D., \& Luthans, F. (1998). Self-efficacy and work-related performance: A meta-analysis. Psychological Bulletin, 124(2), 240-261. https://doi.org/10.1037/00332909.124.2.240

Stoll, G., Rieger, S., Nagengast, B., Trautwein, U., \& Rounds, J. (2021). Stability and change in vocational interests after graduation from high school: A six-wave longitudinal study. Journal of Personality and Social Psychology, 120(4), 1091-1116. https://doi. org/10.1037/pspp0000359

Su, R. (2020). The three faces of interests: An integrative review of interest research in vocational, organizational, and educational psychology. Journal of Vocational Behavior, 116(Part B), 103240. https://doi.org/10.1016/j.jvb.2018.10.016

Su, R., Murdock, C., \& Rounds, J. (2015). Person-environment fit. In APA handbook of career intervention, Volume 1: Foundations. (pp. 81-98). American Psychological Association. https://doi.org/10.1037/14438-005

Theis, L., \& Bipp, T. (2020). Workplace Goal Orientation. European Journal of Psychological Assessment, 36(2), 399-409. https://doi.org/10.1027/1015-5759/a000522

Van Iddekinge, C. H., Putka, D. J., \& Campbell, J. P. (2011). Reconsidering vocational interests for personnel selection: The validity of an interest-based selection test in relation to job knowledge, job performance, and continuance intentions. Journal of Applied Psychology, 96(1), 13-33. https://doi.org/10.1037/a0021193

Van Iddekinge, C. H., Roth, P. L., Putka, D. J., \& Lanivich, S. E. (2011). Are you interested? A meta-analysis of relations between vocational interests and employee performance and turnover. Journal of Applied Psychology, 96(6), 1167-1194. https://doi. org/10.1037/a0024343

Vandewalle, D. (1997). Development and validation of a work domain goal orientation instrument. Educational and Psychological Measurement, 57(6), 995-1015. https://doi. org/10.1177/0013164497057006009

Wilmot, M. P., Wanberg, C. R., Kammeyer-Mueller, J. D., \& Ones, D. S. (2019). Extraversion advantages at work: A quantitative review and synthesis of the meta-analytic evidence. Journal of Applied Psychology, 104(12), 1447-1470. https://doi.org/10.1037/apl0000415 
Yeo, G., Loft, S., Xiao, T., \& Kiewitz, C. (2009). Goal orientations and performance: Differential relationships across levels of analysis and as a function of task demands. Journal of Applied Psychology, 94(3), 710-726. https://doi.org/10.1037/a0015044

Zingoni, M., \& Corey, C. M. (2017). How mindset matters: The direct and indirect effects of employees' mindsets on job performance. Journal of Personnel Psychology, 16(1), 36-45. https://doi.org/10.1027/1866-5888/a000171 